\title{
Pelatihan Penerapan Gizi Seimbang Pada Masa Pandemi Covid-19
}

\author{
Atika Nur Azizah \\ Email: atikanurazizah@ump.ac.id \\ Program Studi Kebidanan, Universitas Muhammadiyah Purwokerto, Indonesia \\ Jl. Letjen Soepardjo Rustam KM. 7 Sokaraja, Kabupaten Banyumas \\ Telp. (0281) 626751
}

\begin{abstract}
Abstrak
Masa pandemi covid-19 (corona virus disease 2019) menyebabkan menurunnya daya tahan tubuh. Hal yang dapat meningkatkan daya tahan tubuh balita salah satunya yaitu makan makanan bergizi seimbang. Tujuan pelatihan penerapan gizi seimbang yaitu meningkatkan pengetahuan dan keterampilan tentang gizi seimbang. Gizi seimbang sangat diperlukan untuk meningkatkan sistem kekebalan tubuh yang baik. Metode pelaksanaan berupa pelatihan dengan metode ceramah, diskusi, dan praktik penerapan gizi seimbang kepada pengurus Pimpinan Cabang Nasyiatul Aisyiyah Rawalo. Hasilnya mengalami peningkatan pengetahuan sebesar $60 \%$ dan peningkatan keterampilan penerapan gizi seimbang sebanyak $85 \%$.
\end{abstract}

Kata kunci: covid-19; gizi seimbang; pelatihan.

\begin{abstract}
The covid-19 pandemic (corona virus disease 2019) causes a decrease in the body's immune system. One of the things that can increase a toddler's immune system is eating a balanced nutritious diet. The purpose of the training on the application of balanced nutrition is to increase knowledge and skills about balanced nutrition. Balanced nutrition is necessary to promote a good immune system. The implementation method is in the form of training with lecture methods, discussions, and the practice of applying balanced nutrition to the management of the Nasyiatul Aisyiyah Rawalo Branch Manager. The result is an increase in knowledge by $60 \%$ and an increase in skills in the application of balanced nutrition by $85 \%$.
\end{abstract}

Keywords: covid-19; balanced nutrition; training 


\section{Pendahuluan}

Coronaviruses (CoV) adalah keluarga besar virus yang menyebabkan penyakit mulai dari flu biasa hingga penyakit yang lebih parah seperti Sindrom Pernafasan Timur Tengah (MERS-CoV) dan Sindrom Pernafasan Akut Parah (SARS-CoV). Penyakit Coronavirus 2019 (COVID-19) adalah virus corona jenis baru yang ditemukan pada tahun 2019 dan belum pernah teridentifikasi pada manusia. Virus corona adalah zoonosis, artinya ditularkan antara hewan dan manusia. Investigasi terperinci menemukan bahwa SARS-CoV ditularkan dari kucing luwak ke manusia dan MERS-CoV dari unta dromedaris ke manusia. Beberapa coronavirus yang dikenal beredar pada hewan yang belum menginfeksi manusia $^{[1]}$

Masa covid-19 (corona virus disease 2019) menyebabkan banyak perubahan dalam kehidupan seharihari. Menjaga pola makan yang gizi seimbang yang sehat sangat penting dalam meningkatkan sistem kekebalan tubuh yang baik sehingga melindungi keluarga dari penularan virus corona. Makan makanan gizi seimbang sangat penting untuk membangun kekebalan tubuh yang kuat agar terlindungi dari infeksi virus serta memberikan perlindungan ekstra bagi tubuh ${ }^{[2]}$

Gizi sangat berperan dalam proses pertumbuhan dan perkembangan otak. Zat gizi yang diperlukan terdiri dari zat gizi mikronutrien dan zat gizi makronutrien. Zat gizi makronutrien terdiri dari energi, protein, dan lemak sedangkan zat gizi mikronutrien terdiri dari vitamin dan mineral ${ }^{[3]}$

Gizi seimbang adalah susunan pangan sehari-hari yang mengandung zat gizi dalam jenis dan jumlah yang sesuai dengan kebutuhan tubuh, dengan memperhatikan prinsip keanekaragaman pangan, aktivitas fisik, perilaku hidup bersih dan memantau berat badan secara teratur dalam rangka mempertahankan berat badan normal untuk mencegah masalah gizi ${ }^{[4]}$

Pedoman gizi seimbang yang dikemas dalam "isi piringku" yang menggambarkan porsi makan yang dikonsumsi dalam satu piring yaitu $50 \%$ karbohidrat dan protein serta $50 \%$ buah dan sayur. Makanan pokok (sumber karbohidrat) sebanyak 2/3 dari $1 / 2$ piring, lauk pauk (sumber protein) sebanyak $1 / 3$ dari $1 / 2$ piring, sayur-sayuran (sumber vitamin dan mineral) sebanyak $2 / 3$ dari $1 / 2$ piring, dan buah-buahan (sumber vitamin dan mineral) sebanyak $1 / 3$ dari $1 / 2$ piring $^{[5]}$

Makanan pokok contohnya beras, jagung, singkong, ubi, talas, sagu, dan produk olahannya. Lauk pauk terdiri dari lauk pauk hewani contohnya daging, unggas, ikan, telur, susu, dan hasil olahannya sedangkan lauk nabati contohnya tahu, tempe, kacang-kacangan. Sayur-sayuran contohnya wortel, bayam, kangkung, selada air, tomat, kol, brokoli, labu siam, rebung, terong, dan lainnya. Buah-buahan contohnya pisang, pepaya, semangka, melon, mangga, jeruk, dan lainnya ${ }^{[5]}$

Berdasarkan hasil Riset kesehatan Dasar Tahun 2018 menyatakan bahwa persentase gizi buruk di Indonesia adalah 3,9\% sedangkan status gizi kurang adalah $13 \%$. Hal tersebut tidak berbeda jauh dengan hasil pemantauan Status Gizi yang diselenggarakan oleh Kementeria Kesehatan tahun 2017 yaitu persentase gizi buruk pada balita usia 0-59 bulan sebesar 3,8\% dan persentase gizi kurang sebesar $14,0 \%{ }^{[6]}$

Upaya mengoptimalkan penyampaian pesan gizi seimbang 
kepada masyarakat dibutuhkan komunikasi, informasi, dan edukasi yang tepat dan berbasis masyarakat. Oleh karena itu perlu diberi informasi tentang gizi seimbang pada era adaptasi kebiasaan baru pandemi covid-19 [4].

Tujuan pelatihan ini adalah untuk meningkatkan pengetahuan dan keterampilan terkait dengan penerapan gizi seimbang sema era kebiasaan baru pandemi covid-19.

\section{Metode}

Kegiatan pelatihan penerapan gizi seimbang balita merupakan salah satu rangkaian kegiatan pengabdian masyarakat yang dilakukan penulis dalam kegiatan Nasyiatul 'Aisyiyah Cabang Rawalo, Kabupaten Banyumas. Dalam kegiatan tersebut dilakukan pelatihan tentang penerapan gizi seimbang paada balita. Jumlah anggota kader Nasyiatul 'Aisyiyah yang hadir pada pelatihan sebanyak 20 kader. Penilaian dilakukan secara serempak kepada kader dengan membagikan kuesioner pretest dan post test yang disebarkan oleh mahasiswa pada saat penyuluhan serta evaluasi penerapan gizi seimbang pada masing-masing kader.

\section{Hasil dan Pembahasan}

Peningkatan pengetahuan dan keterampilan tentang Gizi Seimbang Balita dilakukan pada tanggal 21 Maret 2021, di salah satu rumah kader Nasyiatul 'Aisyiyah Rawalo Kabupaten Banyumas sebanyak 20 kader. Pelatihan yang dilakukan untuk meningkatkan pengetahuan dan keterampilan penerapan gizi seimbang pada balita.

Pemberian pengetahuan tentang gizi seimbang dengan memberikan ceramah tentang definisi, manfaat, jenis-jenis gizi seimbang, fungsu dan contoh masing-masing jenis gizi seimbang, dan cara konsumsi gizi seimbang dengan baik selama era kebiasaan baru dilanjutkan dengan diskusi. Setelah selesai diskusi dilanjutkan dengan pelatihan penerapan gizi seimbang untuk balita yang dilakukan dengan simulasi terlebih dahulu kemudian diikuti oleh seluruh kader.

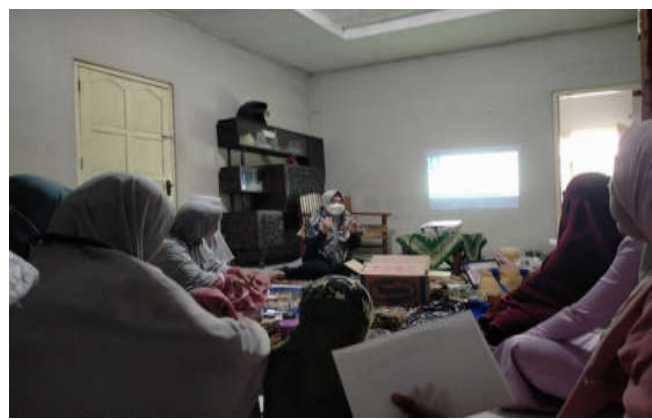

Gambar 3.1. Penulis melakukan Ceramah dan Pelatihan

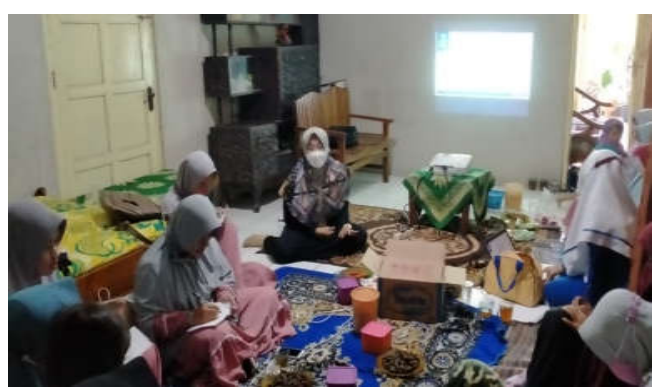

Gambar 3.2. Penulis melakukan Pre Test dan Post Test

Keberhasilan kegiatan peningkatan pengetahuan dan keterampilan penerapan gizi seimbang pada balita terlihat pada tabel berikut: 
Grafik 3.1. Peningkatan Pengetahuan Gizi Seimbang Pada Balita

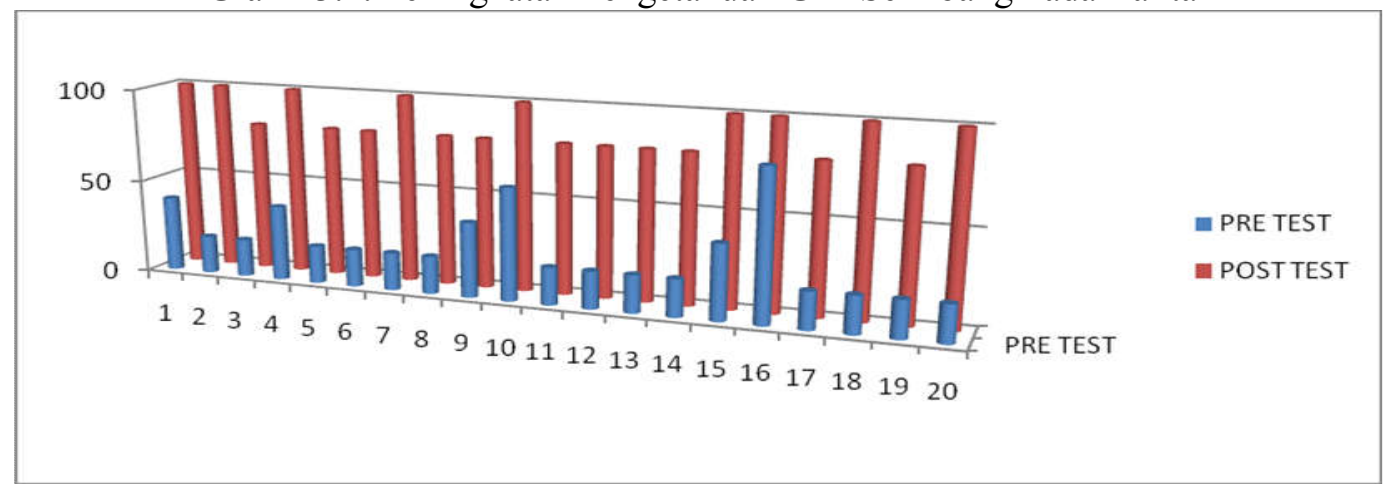

Diagram 3.1. Peningkatan Keterampilan Penerapan Gizi Seimbang Pada Balita Sebelum dan Setelah Pelatihan

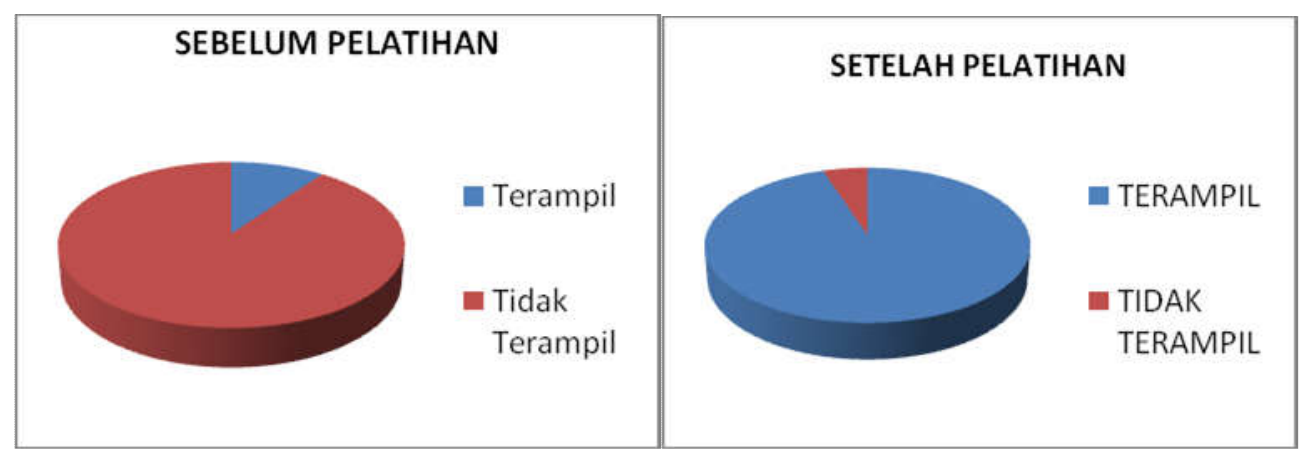

Dari tabel diatas terlihat ada perubahan pengetahuan tentang gizi seimbang pada balita, pengetahuan pada saat pre test sebesar $29 \%$ dan pengetahuan pada saat post test sebesar $89 \%$. Hal tersebut membuktikan terjadi peningkatan pengetahuan tentang gizi seimbang pada balita sebesar $60 \%$.

Pengetahuan merupakan hasil dari tahu dan ini terjadi setelah seseorang melakukan penginderaan terhadap suatu obyek tertentu. Penginderaan ini terjadi melalui panca indera manusia yaitu indera penglihatan, pendengaran, penciuman, rasa dan raba. Sebagian besar pengetahuan manusia diperoleh melalui mata dan telinga. Pengetahuan merupakan domain yang sangat penting untuk terbentuknya perilaku seseorang [7]

Pemberian informasi dapat meningkatkan pengetahuan seseorang, dengan adanya peningkatan pengetahuan maka diharapkan akan terjadi perubahan perilaku yang lebih baik (Machfoedz dan Suryani, 2007). Hal tersebut sesuai dengan teori bahwa pengetahuan kader tentang gizi seimbang didapatkan dari hasil melihat dan mendengarkan ceramah dan pemberian informasi tentang gizi seimbang pada balita dapat meningkatkan pengetahuan pada kader Nasyiatul 'Aisyiyah Rawalo. 


\section{Kesimpulan}

Pelatihan penerapan gizi seimbang pada balita memberi dampak yang sangat baik bagi kader Nasyiatul 'Aisyiyah berupa peningkatan pengetahuan tentang gizi seimbang pada balita sebesar $60 \%$ dan peningkatan keterampilan penerapan gizi seimbang pada balita sebesar $85 \%$.

\section{Daftar Pustaka}

[1] Gugusan Tugas
$\begin{aligned} & \text { Percepatan } \\ & \text { Penanganan } \\ & \text { "Protokol }\end{aligned}$ penanganan pandemi covid-19 (Corona Virus Disease 2019)," 2020.

https://coronavirus.jhu.edu/ma p.html.

[2] Kemenkes RI, Panduan Gizi Seimbang Pada Masa Pandemi Covid-19. Jakarta: Kemenkes, 2020.
[3] F. Jalal, Literasi Gizi Pada Masa Adaptasi Kebiasaan Baru. Jakarta: Direktorat Sekolah Dasar, 2020.

[4] Permenkes RI Nomor 41 tahun 2014, Pedoman Gizi Seimbang. Jakarta: Menteri Kesehatan RI, 2014.

[5] Kemenkes RI, Pusat Data dan Informasi. Jakarta Selatan, 2019.

[6] Kemenkes RI, Profil Kesehatan Indonesia 2018. 2019.

[7] Notoatmodjo, Ilmu Perilaku Kesehatan. Jakarta: Rineka Cipta, 2010.

[8] I. Machfoedz and E. Suryani, Pendidikan Kesehatan Bagian dari Promosi Kesehatan. Yogyakarta: Fitramaya, 2007. 